\title{
The Effects of Oleuropein on Apoptotic Rate and Oxidative Stress Profiles during Tumour Promotion Stage in the Mouse Skin Carcinogenesis Model \\ (Kesan Oleuropein atas Kadar Apoptosis dan Tekanan Oksidatif Profil semasa Peringkat Galakan Tumor dalam Model Karsinogenesis Kulit Tikus)
}

\author{
Siti FATHIAH MASRE*, AZIM IZZUDDEEN, DAYANG NOOR SUZLIANA JOHN \& ZARIYANTEY AbDUl HAMID
}

\begin{abstract}
Oleuropein is a phenolic compound that can be abundantly found in the olive plant and it possesses pharmacological properties including anticancer, antioxidant, and anti-inflammatory. This present study was designed to determine the effects of oleuropein on tumour promotion stage, particularly on the histopathological changes, apoptotic rates and oxidative stress profiles by using the mouse skin carcinogenesis model. Female ICR mice were randomly divided into 3 groups ( $\mathrm{n}=8$ mice per group) as follows: Control induced with DMBA/TPA, negative control (acetone) and oleuropeintreated groups. For the treatment group, the mice were initiated with DMBA (200 nmol) followed by pre-treatment with oleuropein $(10 \mathrm{mg} / \mathrm{kg})$ and subsequent promotion with TPA $(20 \mathrm{nmol})$. The treatments were topically applied on the shaved dorsal up to 10 weeks. Histopathology analysis showed that oleuropein-pretreated group appeared lack of thickness in epidermal hyperplasia, as compared to thick hyperplasia and epidermal disorganisation in the DMBA TPA control group. Data also showed that oleuropein pre-treatment resulted in a significant increase of the apoptotic rates $(\mathrm{p}<0.05)$ as indicated by the activated caspase-3 labelling compared to DMBA/TPA group. Interestingly, the level of MDA is significantly reduced $(\mathrm{p}<0.05)$ in the oleuropein pre-treated group compared to DMBA/TPA group. Next, pretreatment of oleuropein caused a significant decrease in the GSH levels $(\mathrm{p}<0.05)$ along with a significant increase in the SOD levels $(\mathrm{p}<0.05)$ compared to the DMBA/TPA group. Overall, this study indicates that oleuropein may act as a potential chemopreventive agent through its apoptotic and antioxidant defence activities on tumour promotion stage in skin carcinogenesis event.
\end{abstract}

Keywords: Carcinogenesis; chemoprevention; oleuropein; skin cancer; tumour promotion

\section{ABSTRAK}

Oleuropein adalah sebatian fenolik yang banyak ditemui dalam pokok zaitun dan ia mempunyai beberapa aktiviti farmakologi termasuk antikanser, antioksidan dan anti-inflamasi. Kajian ini dijalankan untuk menentukan kesan oleuropein pada peringkat galakan tumor terhadap perubahan histopatologi, kadar apoptosis dan profil tekanan oksidatif dalam model karsinogenesis kulit tikus. Tikus ICR betina dibahagikan secara rawak kepada 3 kumpulan ( $\mathrm{n}=8$ tikus setiap kumpulan): Kawalan induksi dengan DMBA/TPA, kawalan negatif (aseton) dan kumpulan pra-rawatan oleuropein. Bagi kumpulan rawatan, tikus akan diinduksi dengan DMBA (200 nmol) diikuti dengan pra-rawatan oleuropein (10 mg/kg) sebelum diaruh dengan TPA $(20 \mathrm{nmol})$ secara topikal atas bahagian dorsal sehingga $10 \mathrm{minggu}$. Analisis histopatologi menunjukkan bahawa kumpulan yang dirawat dengan oleuropein kelihatan kekurangan ketebalan epidermis hiperplasia, justeru, menghentikan peringkat galakan tumor berbanding dengan ketebalan hiperplasia dan ketidakaturan susunan epidermis pada kumpulan kawalan DMBA/TPA. Data juga menunjukkan bahawa kumpulan pra-rawatan oleuropein menghasilkan kenaikan signifikan kadar apoptosis $(\mathrm{p}<0.05)$ melalui pengaktifan caspase-3 bertanda berbanding kumpulan DMBA/TPA. Menariknya, tahap MDA menunjukkan pengurangan signifikan $(\mathrm{p}<0.05)$ dalam kumpulan pra-rawatan oleuropein berbanding kumpulan DMBA/TPA. Seterusnya, pra-rawatan oleuropein menyebabkan penurunan signifikan pada paras GSH $(\mathrm{p}<0.05)$ beserta peningkatan signifikan pada paras $S O D(\mathrm{p}<0.05)$ berbanding kumpulan DMBA/TPA. Secara keseluruhannya, kajian ini menunjukkan bahawa oleuropein berpotensi bertindak sebagai agen kemohalang melalui aktiviti apoptotik dan pertahanan antioksidan pada peringkat promosi tumor dalam karsinogenesis kulit.

Kata kunci: Kanser kulit; karsinogenesis; kemohalang; oleuropein; promosi tumor

\section{INTRODUCTION}

Cancer is a rising health concern worldwide with being specifically connected to the massive changes toward an inactive lifestyle and subsequent modification of the environments (Bishayee \& Sethi 2016). Recently, there are great evidences showed the potential role of natural products from various medicinal plants in conferring chemopreventive properties that can interfere tumour 
carcinogenesis events (Basri et al. 2016; Harun \& Ghazali 2012; Neergheen et al. 2010; Zaila et al. 2013). Chemopreventive phytochemicals may serve as alternative agent to reverse, delay or inhibit tumour initiation, promotion or progression (Neergheen et al. 2010; Salleh et al. 2011).

Oleuropein that is generally known as one of the most notable phenolic compound in olive plant (Omar 2010) has shown to have several pharmacological functions comprising anticancer (Shamshoum et al. 2017), antioxidant (Barbaro et al. 2014), anti-inflammatory (Qabaha et al. 2017) and antiviral (Micol et al. 2005). Past studies have demonstrated that oleuropein induced apoptotic activities and suppressed tumour growth in different cancer cells including hepatocellular carcinoma (Yan et al. 2015) and promyelocytic leukemia (Anter et al. 2011). Though many studies have documented on the anticancer effects of oleuropein on various cancer types, yet the preventive effect of oleuropein specifically at the tumour promotion stage is still undetermined. Therefore, this present study will assess the potential effects of oleuropein on tumour promotion by using a two-stage skin carcinogenesis model.

The two-stage skin carcinogenesis model topically induced by DMBA/TPA on mouse is one of the best in vivo models to be used for tumour development studies in stages involving initiation and promotion stages (Abel et al. 2009; Lindner 2014). It is said that oxidative stress could contributes to trigger the development of cancer in the initiation and promotion stages (Strzelczyk \& Wiczkowski 2012). Moreover, the oxidative stress is proven to play a pro-neoplastic role in the promotion stage by inhibiting apoptotic activities (Liu et al. 2005). Thus, this study aimed to determine whether oleuropein could prevent the promotion stage by using the two-stage skin carcinogenesis model focusing on the analysis of the apoptotic rate and oxidative stress profiles.

\section{MATERIALS AND METHODS}

\section{ANIMALS}

Seven to eight-week old female ICR mice $(n=24)$ weighing from $20 \mathrm{~g}$ to $30 \mathrm{~g}$ were obtained from the Animal Resource Unit, Faculty of Health Sciences, Universiti Kebangsaan Malaysia (UKM). The animals were housed in polypropylene cages at room temperature and $12 \mathrm{~h}$ light and dark cycles in the animal house of our faculty with free access to standard mouse pellet diet and fresh tap water $\mathrm{ad}$ libitum. Animal welfare and experimental procedures in this study were approved by the animal ethics committee of UKM (approval number: FSK/2016/FATHIAH/28-SEPT./795SEPT.-2016-APR.-2018).

\section{CHEMICALS AND REAGENTS}

Oleuropein, 7,12-dimethylbenz(a)anthracene (DMBA), and 12-O-tetradecanoylphorbol-13-acetate (TPA) were purchased from Sigma-Aldrich, United States.

\section{TWO-STAGE SKIN CARCINOGENESIS MODEL}

The dorsal part of the animals was shaved with an electric hair clipper by two days before the beginning of experiment. Total of 24 ICR mice was randomly divided into three groups ( $n=8$ mice per group) that comprised of two control groups and one treatment group. The first control group received topical application of $200 \mathrm{nmol}$ of DMBA in $100 \mu \mathrm{L}$ acetone on week one and $20 \mathrm{nmol}$ of TPA in $100 \mu \mathrm{L}$ acetone for twice per week on week $2^{\text {nd }}$ until week $10^{\text {th }}$; while the second control group received acetone alone $(100 \mu \mathrm{L})$. Mice in group 3 received the same treatment of DMBA/TPA as in group 1, and the animals were pretreated with oleuropein, $10 \mathrm{mg} / \mathrm{kg}$ body weight (Kimura \& Sumiyoshi 2009) 30 min before the TPA induction for twice per week until week $10^{\text {th }}$.

\section{HISTOPATHOLOGICAL ANALYSIS}

All animals were sacrificed one week after the final treatment. The skin tissues on the dorsal part were biopsied and one-half of the tissues was fixated in 10\% neutral buffered formalin for $48 \mathrm{~h}$ and then transferred to $70 \%$ ethanol for tissue processing. Next, processed tissues were embedded in paraffin wax before sectioned to $5 \mu \mathrm{m}$ thickness and stained with the Haematoxylin and Eosin (H\&E) staining. The stained sections were observed under the light microscope for histopathological changes.

\section{ANALYSIS OF APOPTOTIC ACTIVITIES}

Immunohistochemistry (IHC) staining on active caspase-3 was performed to determine the apoptotic activity. Tissue sections were deparaffinized in xylene and dehydrated in absolute alcohol. The deparaffinized tissue sections were boiled in commercial citrate buffer for antigen retrieval between 2 and $4 \mathrm{~min}$. Next, to suppress the endogenous peroxidase activity, the tissue sections were treated with $3 \%$ hydrogen peroxide solution before treated with blocking serum for $10 \mathrm{~min}$. The sections were incubated with primary antibody of an activated caspase-3 (Cell Signaling Technology) for overnight at $4^{\circ} \mathrm{C}$. On the next day, the sections were washed in phosphate buffered saline (PBS) before incubated with secondary horseradish peroxidaseconjugated antibody for $1 \mathrm{~h}$, at room temperature. The brown colour was developed on the sections with DABperoxidase reaction. The sections on slide were mounted and covered with coverslip followed visualization under the light microscope. To determine the rate of apoptotic activities, data was presented as the percentage (\%) of number of apoptotic cells expressed as positive labelled cells for active caspase- 3 from total of 100 cells in each area under a $20 \times$ magnification.

\section{MEASURING OXIDATIVE STRESS AND ANTIOXIDANTS LEVELS}

Another half of the biopsied tissues was homogenized using a homogenizer in PBS (0.1M, pH7.4). The homogenized tissue was centrifuged at $3000 \mathrm{rpm}$ for $20 \mathrm{~min}$, at $4^{\circ} \mathrm{C}$ 
temperature to obtain the supernatant. The protein content in the supernatant was assayed using the Lowry method. The estimation of malondialdehyde (MDA) levels that indicates lipid peroxidation together with reduced glutathione (GSH) and superoxide dismutase (SOD) antioxidants levels in each group were analysed in this study. MDA level was assayed according to the reaction of MDA with thiobarbituric acid (TBA) in resulting a pink coloured chromogen of TBA reactive substances (TBARS) and then measured at $532 \mathrm{~nm}$ (Stocks \& Dormandy 1971). The level of GSH was determined according to reaction of GSH with 5,5-dithiobis-2-nitrobenzoic acid (DTNB) in resulting a yellow coloured chromogen and then measured at $412 \mathrm{~nm}$ (Ellman 1959). For the level of SOD, it was measured according to reaction of SOD with superoxide in resulting a purple coloured chromogen and then measured at $560 \mathrm{~nm}$ (Beyer \& Fridovich 1987).

\section{STATISTICAL ANALYSIS}

All data was statistically analysed using the SPSS statistics software version 22. One-way analysis of variance (ANOVA) with Tukey's post hoc test was used to analyse the level of significance between groups. All data was presented in mean and standard error of mean (mean \pm SEM) with significant values of $p<0.05$.

\section{RESULTS AND DISCUSSION}

\section{HISTOPATHOLOGY ANALYSIS}

Histopathological changes in the two-stage skin carcinogenesis model on week 10 were demonstrated in Figure 1(a)-1(c). DMBA/TPA control group displayed thick epidermal hyperplasia together with incoherence arrangement of epithelial cells. In contrast, negative control group showed no changes with a normal single layer of cells. Interestingly, oleuropein pre-treated group depicted mild hyperplasia with a mixture of a normal single epithelial cell, thus indicate a potential effect of oleuropein to prevent the tumour promotion stage.

Two-stage skin carcinogenesis model has been used widely to study multi-stage events in the epithelial tumour development from the initiation stage to promotion stage (Masre et al. 2017; Neagu et al. 2016; Rundhaug \& Fischer 2010). Study on the anti-tumour at promotion stage is appraised as the most constructive mode in the field of cancer chemoprevention in regards to reversible factor during the promotion stage compared with the initiation stage which is irreversible (Konoshima \& Takasaki 2000). From our histopathology findings, pre-treatment of oleuropein before TPA-induced promotion stage may have reduced the hyperplastic conditions as indicated with the presence of normal single layer of cells. This is in contrast to the DMBA/TPA control group that appeared with thicker hyperplasia and massive disorganization of epithelial cells. This current data is coincided with previous study on oleuropein treatment that resulted in the reduction of epidermal thickness and tumour incidence on the skin exposed to UVB (Kimura \&Sumiyoshi 2009).

\section{ANALYSIS OF APOPTOTIC ACTIVITY}

Immunohistochemistry staining that targeted to the active caspase-3 protein was performed on the skin tissues to indicate the status of apoptotic activity (Figure 2). Based on the data, oleuropein pre-treated group showed several apoptotic cells that can be seen through activated caspase-3 brown labelling (Figure 2(a)-arrows). However, there was little to no distribution of apoptotic cells appeared in both DMBA/TPA and negative control groups (Figure 2(b) and 2(c)). Moreover, the rate of apoptotic activity (\%) by activated caspase-3 labelling was also assessed in each group (Figure 3). From our data, significant increased $(p<0.05)$ of apoptotic rates $(\%)$ was displayed in the oleuropein pre-treated group $(14.67 \pm 0.6 \%)$ as compared to the DMBA/TPA group $(2.0 \pm 0.2 \%)$ and negative control group $(0.67 \pm 0.15 \%)$.

To examine the apoptotic activities, IHC analysis of activated caspase- 3 that indicates a main executioner apoptosis was conducted in this study. From our data, pre-treatment of oleuropein have displayed the potential to induce pre-cancerous cell death during tumour promotion stage. This is in accordance to the past study that showed induction of apoptosis by oleuropein on hepatocellular carcinoma HepG2 cells and breast cancer MDA-MB-231
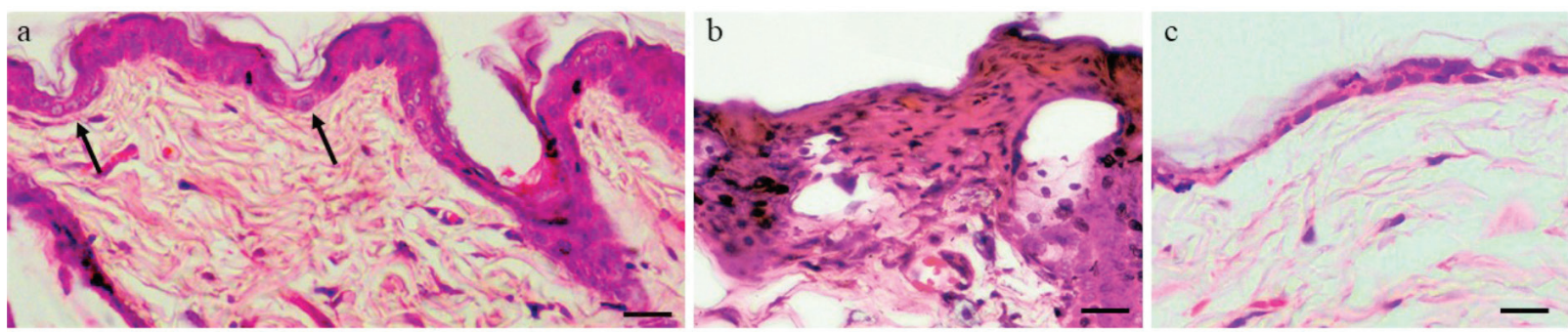

FIGURE 1. Histopathology analysis of two-stage skin carcinogenesis in mouse model (a) Pre-treatment of oleuropein before promotion stage showed a histotype of very mild hyperplasia with a mixture of normal single layer of epithelial cells as shown in arrows. This indicates that oleuropein could have altered the promotion stage causing reduction in the thickness of epidermal hyperplasia, (b) DMBA/TPA control group showed thick epidermal hyperplasia with massive disorganisation of epithelial cells and

(c) Negative control group stayed normal with a single layer of epithelial cells (Magnification $\times 40$ ) 

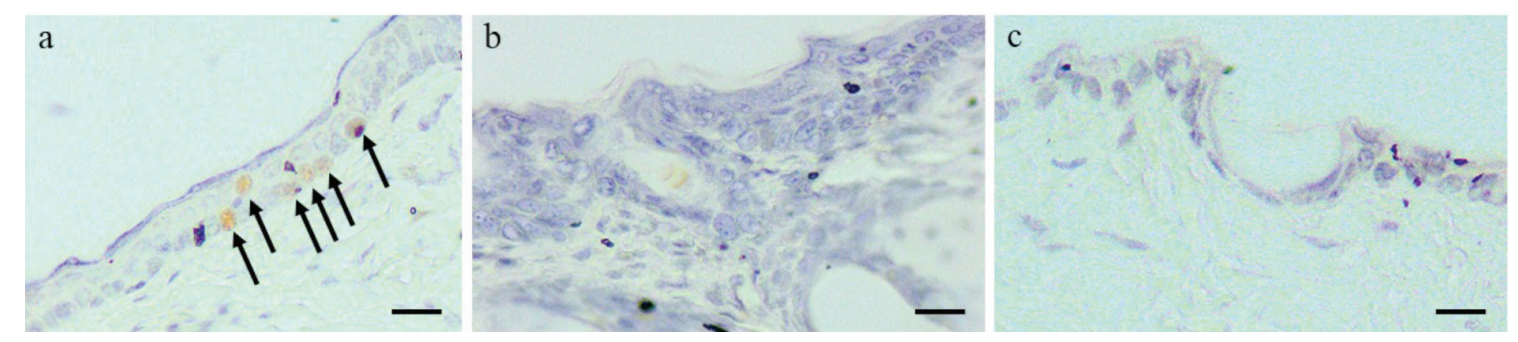

FIGURE 2. The expression of active caspase-3 protein by immunohistochemistry staining (a) Few numbers of apoptotic cells (arrows) appeared to be distributed in the epithelial linings of oleuropein pre-treated group. Little to no appearance of apoptotic cells was depicted in the (b) DMBA/TPA group and (c) negative control group (Magnification $\times 40$ )

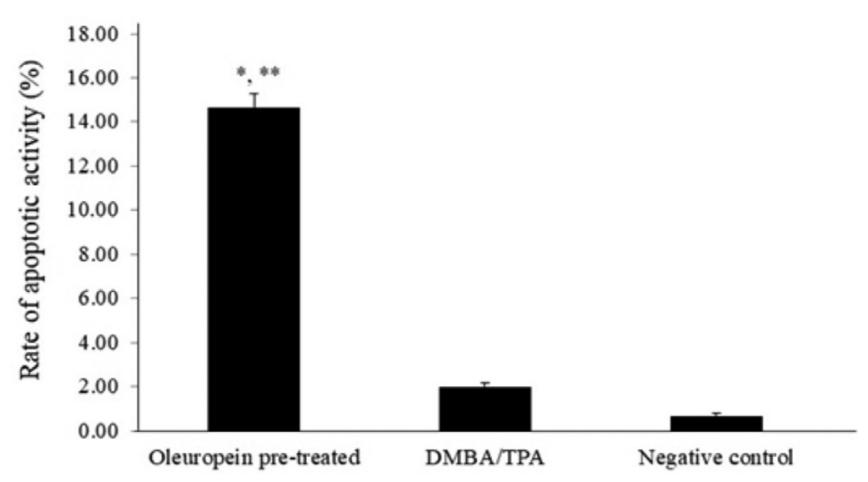

FIGURE 3. The rate of apoptotic activity $(\%)$ in oleuropein pre-treated, DMBA/TPA and negative control groups. Oleuropein pre-treated group showed a significant increase $(p<0.05)$ of the apoptotic rates $(\%)$ compared with DMBA/TPA* and negative control** groups

cells as mediated via upregulation of activated caspase-3 (Elamin et al. 2013; Yan et al. 2015). In addition, oleuropein has also been documented to exhibit a specific apoptotic activity on cancer cells than on the normal cells (Elamin et al. 2013). Importantly, oleuropein has shown a very high safety profile where it has been given up to $1000 \mathrm{mg} / \mathrm{kg}$ to rats and mice with no remarkable evidences of adverse effects (DelBoccio et al. 2003; Kimura \& Sumiyoshi 2009).

\section{OXIDATIVE STRESS AND ANTIOXIDANTS LEVELS}

The levels of lipid peroxidation (MDA) that signify the status of oxidative stress in the oleuropein pre-treated and control groups are shown in Table 1. MDA levels appeared significantly higher $(p<0.05)$ in the DMBA/TPA control group $(4.63 \pm 0 / 41 \mathrm{nmol} / \mathrm{mg})$ compared to oleuropein pre-treated $(3.44 \pm 0.66 \mathrm{nmol} / \mathrm{mg})$ and negative control $(3.17 \pm 0.45 \mathrm{nmol} / \mathrm{mg})$ groups. Oxidative stress can involve in the pathogenesis of cancer leading to greater damages on cellular components (Yoshikawa \& Naito 2002). This study indicates that the MDA level has significantly increased owing to oxidative damages that may have occurred following exposure to DMBA/TPA carcinogenic agents. Previous study has shown a significant increase of oxidative DNA damage upon TPA induction on mouse skin (Kim et al. 2007). It is also said that oxidative stress can trigger tumour promotion by inhibiting apoptotic activities (Liu et al. 2005). As the MDA level in the oleuropein pretreated group was significantly lower than the DMBA/TPA group, thus, this may reflect the protective potential of oleuropein against the oxidative damage. Moreover, the significance increased of the MDA level may be linked to the low apoptotic rates (\%) in the DMBA/TPA group (Figure 2(b)).

The level of GSH that acts as a key role in the nonenzymatic antioxidant defence system was measured in this study (Table 1). According to the data, DMBA/TPA control group showed the highest level of GSH $(2.87 \times 10$ $3 \pm 3.11 \times 10-4 \mathrm{nmol} / \mathrm{mg}$ ) whilst low level of GSH displayed in the negative control $(2.35 \times 10-3 \pm 1.01 \times 10-4 \mathrm{nmol} / \mathrm{mg})$ and oleuropein pre-treated $(1.76 \times 10-3 \pm 1.86 \times 10-4 \mathrm{nmol} /$ $\mathrm{mg}$ ) groups. Statistical analysis showed a significant difference $(p<0.05)$ in the GSH levels between DMBA/ TPA and treatment groups. In addition, the level of SOD that plays a role in the enzymatic antioxidant defence system was also measured in this study (Table 1). SOD levels appeared highly in the oleuropein pre-treated group $(0.73 \pm 0.05 \mu / \mathrm{mg})$, followed by negative control $(0.63 \pm 0.03$ $\mu / \mathrm{mg})$ and DMBA/TPA control groups $(0.57 \pm 0.24 \mu / \mathrm{mg})$. Statistical analysis showed a significant difference $(p<0.05)$ in the SOD levels between oleuropein pre-treated and DMBA/ TPA control groups.

For the antioxidants status, the measurement of GSH and SOD levels was performed in this study. Both GSH and SOD play an important role as protective antioxidants during oxidative damage (Ighodaro \& Akinloye 2017; Thorsen 2012). Interestingly, the GSH level was 
TABLE 1. MDA, GSH and SOD levels in DMBA/TPA control, negative control and oleuropein pre-treated groups

\begin{tabular}{llll}
\hline Parameters & DMBA/TPA control & Negative control & Oleuropein pre-treated \\
\hline MDA levels $(\mathrm{nmol} / \mathrm{mg})$ & ${ }^{*} 4.63 \pm 0 / 41$ & $3.17 \pm 0.45$ & $3.44 \pm 0.66$ \\
GSH levels $(\mathrm{nmol} / \mathrm{mg})$ & $* 2.87 \times 10^{-3} \pm 3.11 \times 10^{-4}$ & $2.35 \times 10^{-3} \pm 1.01 \times 10^{-4}$ & $* 1.76 \times 10^{-3} \pm 1.86 \times 10^{-4}$ \\
SOD levels $(\mu / \mathrm{mg})$ & ${ }^{a} 0.57 \pm 0.24$ & $0.63 \pm 0.03$ & ${ }^{\mathrm{a}} 0.73 \pm 0.05$ \\
\hline
\end{tabular}

Data was presented in mean \pm SEM, \#significantly difference of DMBA/TPA control with negative control and oleuropein pre-treated groups $(p<0.05$ ), *significantly difference between DMBA/TPA control and oleuropein pre-treated groups $(p<0.05)$, asignificantly difference between oleuropein pre-treated and DMBA/TPA control groups $(p<0.05)$

significantly lower $(p<0.05)$ in the oleuropein pre-treated group compared to DMBA/TPA group. It has been shown that the activation of apoptosis by anticancer agents was triggered by the downregulation of GSH levels (Friesen et al. 2004). Thus, the significant low level of GSH $(p<0.05)$ in the oleuropein pre-treated group is responsible to the significant increase $(p<0.05)$ of apoptotic rates upon treatment with oleuropein in this study. Moreover, as it is proven that oxidative stress is elevated during the initiation and promotion stages (Strzelczyk \& Wiczkowski 2012), thus, the presence of free radicals during carcinogenesis may possibly influence the level of GSH (Lagman et al. 2015) leading to its depletion as shown in our finding. For the SOD levels, significantly increased $(p<0.05)$ in the oleuropein pre-treated group was shown in this study. This finding is in line to the previous study that depicted significant elevation of SOD levels upon treatment with oleuropein leading to growth inhibition of breast cancer (Milanizadeh et al. 2014). With that, present study indicates that oleuropein induced the SOD level while causing reduction of GSH level during tumour promotion stage. The likely explanation could be that the potential suppressive effects of oleuropein on free radicals' production from oxidative damage could be mediated through its differential effects in targeting the antioxidants. However, further investigations are required to clarify that.

\section{CONCLUSION}

In conclusion, pre-treatment of oleuropein in the tumour promotion stage have shown the ability to reduce the thickness in epidermal hyperplasia and significantly promote apoptotic activities. Moreover, pre-treatment of oleuropein showed significant low level of MDA indicating a potential role of oleuropein to protect the epithelial cells from oxidative damage at the promotion stage. This possible protective sign has been further demonstrated through the antioxidants GSH and SOD levels in this study. Overall, oleuropein has potential effects to increase apoptotic rates, act as a protective antioxidant and reduce oxidative stress. Therefore, oleuropein could be further investigated and developed as a chemopreventive agent in skin carcinogenesis or other epithelial cancers via its apoptotic and antioxidant activities on tumour promotion.

\section{ACKNOWLEDGEMENTS}

This study is financially funded by a research grant scheme (GGPM-2016-060) from the Universiti Kebangsaan Malaysia. The authors also would like to express their gratitude to all the academicians and staff in the Biomedical Science Programme, Faculty of Health Sciences, Universiti Kebangsaan Malaysia that are directly or indirectly supporting this study.

\section{REFERENCES}

Abel, E.L., Angel, J.M., Kiguchi, K. \& DiGiovanni, J. 2009. Multi-stage chemical carcinogenesis in mouse skin: Fundamentals and applications. Nature Protocols 4(9): 1350-1362.

Anter, J., Fernandez-Bedmar, Z., Villatoro-Pulido, M., DemydaPeyras, S., Moreno-Millan, M., Alonso-Moraga, A., MunozSerrano, A. \& Luque de Castro, M.D. 2011. A pilot study on the DNA-protective, cytotoxic and apoptosis-inducing properties of olive-leaf extracts. Mutation Research 723(2): 165-170.

Barbaro, B., Toietta, G., Maggio, R., Arciello, M., Tarocchi, M., Galli, A. \& Balsano, C. 2014. Effects of the olive-derived polyphenol oleuropein on human health. International Journal of Molecular Sciences 15(10): 18508-18524.

Basri, D.F., Alamin, Z.A.Z. \& Chan, K.M. 2016. Assessment of cytotoxicity and genotoxicity of stem bark extracts from Canarium odontophyllum Miq. (dabai) against HCT 116 human colorectal cancer cell line. BMC Complementary and Alternative Medicine 16(36): 1-12.

Beyer, W.F. \& Fridovich, I. 1987. Assaying for superoxide dismutase activity: Some large consequences of minor changes in condition. Analytical Biochemistry 161: 559-566.

Bishayee, A. \& Sethi, G. 2016. Bioactive natural products in cancer prevention and therapy: Progress and promise. Seminars in Cancer Biology 40-41: 1-3.

DelBoccio, P., DiDeo, A., DeCurtis, A., Celli, N., Lacoviello, L. \& Rotilio, D. 2003. Liquid chromatography-tandem mass spectrometry analysis of oleuropein and its metabolite hydroxytyrosol in rat plasma and urine after oral administration. Journal of chromatography B, Analytical Technologies in the Biomedical and Life Sciences 785(1): 47-56.

Elamin, M.H., Daghestani, M.H., Omer, S.A., Elobeid, M.A., Virk, P., Al-Olayan, E.M., Hassan, Z.K., Mohammed, O.B. \& Aboussekhra, A. 2013. Olive oil oleuropein has anti-breast cancer properties with higher efficiency on ER-negative cells. Food and Chemical Toxicology 53: 310-316.

Ellman, G.L. 1959. Tissue sulfhydryl groups. Archives of Biochemistry and Biophysics 82: 70-77. 
Friesen, C. \& Debatin, K.M. 2004. A critical role of glutathione in determining apoptosis sensitivity and resistance in leukemia cells. Cell Death and Differentiation 1: s73-s85.

Harun, Z. \& Ghazali, A.R. 2012. Potential chemoprevention activity of pterostilbene by enhancing the detoxifying enzymes in the HT-29 cell line. Asian Pacific Journal of Cancer Prevention 13(12): 6403-6407.

Ighodaro, O.M. \& Akinloye, O.A. 2017. First line defence antioxidants-superoxide dismutase (SOD), catalase (CAT) and glutathione peroxidase (GPX): Their fundamental role in the entire antioxidant defence grid. Alexandria Journal of Medicine doi: 10.1016/j.ajme.2017.09.001

Kim, M.O., Kim, S.H., Shin, M.J., Yu, D.H., Kim, B.S., Chang, K.T., Lee, S., Park, Y.B., Lee, T.H. \& Rhoo, Z.Y. 2007. DMBA/TPA-induced tumour formation is aggravated in human papillomavirus type 16 E6/E7 transgenic mouse skin. Oncology Research 16(7): 325-332.

Kimura, Y. \& Sumiyoshi, M. 2009. Olive leaf extract and its main component oleuropein prevent chronic ultraviolet B radiation-induced skin damage and carcinogenesis in hairless mice. Journal of Nutrition 139(11): 2079-2086.

Konoshima, T. \& Takasaki, M. 2000. Anti-tumor-promoting activities (cancer chemopreventive activities) of natural products. Studies in Natural Products Chemistry 24: 215-267.

Lagman, M., Ly, J., Saing, T., Singh, M.K., Tudela, E.V., Morris, D., Chi, P.T., Ochoa, C., Sathananthan, A. \& Venketaraman, V. 2015. Investigating the causes for decreased levels of glutathione in individuals with type II diabetes. Plos ONE 10(3): e0118436.

Lindner, D. 2014. Animal models and the tumor microenvironments: Studies of tumor-host symbiosis. Seminars in Oncology 41(2): 146-155.

Liu, Y., Borchert, G.L. \& Donals, S.P. 2005. MnSOD inhibits proline oxidase-induced apoptosis in colorectal cancer cells. Carcinogenesis 26: 1335-1342.

Masre, S.F., Rath, N., Olson, M.F. \& Greenhalgh, D.A. 2017. $\mathrm{ROCK} 2 / \mathrm{ras}^{\mathrm{Ha}}$ co-operation induces malignant conversion via p53 loss, elevated NF- $\kappa \beta$ and tenascin C-associated rigidity, but $\mathrm{p} 21$ inhibits ROCK2/NF- $\mathrm{k} \beta$-mediated progression. Oncogene 36: 2529-2542.

Micol, V., Caturla, N., Perez-Fons, L., Mas, V., Perez, L. \& Estepa, A. 2005. The olive leaf extract exhibits antiviral activity against viral haemorrhagic septicaemia rhabdovirus (VHSV). Antiviral Research 66(2-3): 129-136.

Milanizadeh, S., Bigdeli, M.R., Rasoulian, B.\& Amani, D. 2014. The effects of olive leaf extract on antioxidant enzymes activity and tumor growth in breast cancer. Thrita 3(1): e12914.

Neagu, M., Caruntu, C., Constantin, C., Boda, D., Zurac, S., Spandidos, D. \& Abd Tsatsakis, A.M. 2016. Chemically induced skin carcinogenesis: Updates in experimental models (review). Oncology Reports 35(5): 2516-2528.

Neergheen, V.S., Bahorun, T., Taylor, E.W., Jen, L.S. \& Aruoma, O.I. 2010. Targeting specific cell signalling transduction pathways by dietary and medicinal phytochemicals in cancer chemoprevention. Toxicology 278(2): 229-241.
Omar, S.H. 2010. Oleuropein in olive and its pharmacological effects. Scientia Pharmaceutica 78(2): 133-154.

Qabaha, K., AL-Rimawi, F., Qasem, A. \& Naser, S.A. 2017. Oleuropein is responsible for the major anti-inflammatory effects of olive leaf extract. Journal of Medicinal Food doi: org/10.1089/jmf.2017.0070.

Rundhaug,J.E. \& Fischer, S.M. 2010. Molecular mechanisms of mouse skin tumor promotion. Cancers 2: 436-482.

Salleh, S.A., Rajab, N.F., Abdullah, N.R., Ismail, Z., Mouatt, P., Dowell, A. \& Muhamad, S. 2011. In vitro chemopreventive activity of an ethyl acetate fraction derived from hot water extract of Orthosiphon stamineus in HepG2 cells. Journal of Medicinal Plant Research 5(10): 1892-1899.

Shamshoum, H., Vlavcheski, F. \& Tsiani, E. 2017. Anticancer effects of oleuropein. Biofactors 43(4): 517-528.

Stocks, J. \& Dormandy, T.L. 1971. The autoxidation of human red cell lipids induced by hydrogen peroxide. British Journal of Haematology 20: 95-111.

Strzelczyk, J.K. \& Wiczkowski,A. 2012. Oxidative damage and carcinogenesis. Contemporary Oncology 16(3): 230-233.

Thorsen, M., Jacobson, T., Vooijs, R., Navarrete, C., Bliek, T., Schat, H. \& Tamas, M.J. 2012. Glutathione serves an extracellular defence function to decrease arsenite accumulation and toxicity in yeast. Molecular Microbiology 84(6): 1177-1188.

Yan, C.M., Chai, E.Q., Cai, H.Y., Miao, G.Y. \& Ma, W. 2015. Oleuropein induces apoptosis via activation of caspases and suppression of phosphatidylinositol 3-kinase/protein kinase B pathway in HepG2 human hepatoma cell line. Molecular Medicine Reports 11(6): 4617-4624.

Yoshikawa, T. \& Naito, Y. 2002. What is oxidative stress. Japan Medical Association Journal 45(7): 271-276.

Zaila, C.F.S., Zuraina, M.Y.F., Norfazlina, M.N., Mun, L.L., Nurshahirah, N., Florinsiah, L. \& Rajab, N.F. 2013. Antiproliferative effect of Lignosus rhinocerotis, the Tiger Milk mushroom on HCT 116 human colorectal cancer cell. The Open Conference Proceeding Journal 4(2): 65-70.

Biomedical Science Programme

Centre of Health and Applied Sciences

Faculty of Health Sciences, Universiti Kebangsaan Malaysia

Jalan Raja Muda Aziz, 50300 Kuala Lumpur, Federal Territory Malaysia

*Corresponding author; email: sitifathiah@ukm.edu.my

Received: 19 February 2018

Accepted: 5 June 2018 